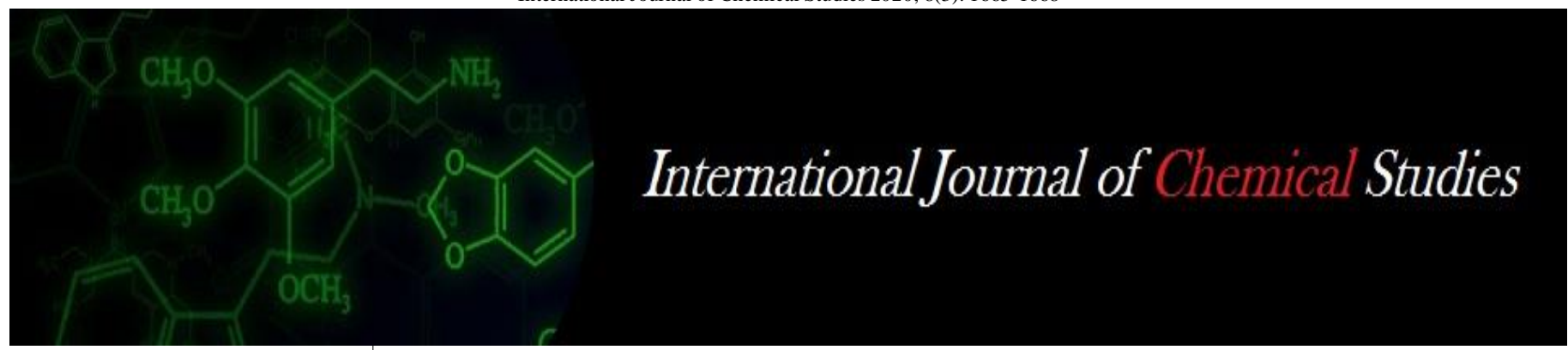

P-ISSN: 2349-8528

E-ISSN: 2321-4902

www.chemijournal.com

IJCS 2020; 8(3): 1665-1668

(C) 2020 IJCS

Received: 08-03-2020

Accepted: 10-04-2020

Dr. Afifa Jahan

Scientist, Krishi Vigyan Kendra

Palem, Nagarkurnool,

Telangana, India

\section{Mandla Rajashekhar}

Scientist, Krishi Vigyan Kendra

Palem, Nagarkurnool,

Telangana, India

Dr. T Prabhakar Reddy

Senior Scientist and Head, Krishi

Vigyan Kendra Palem,

Nagarkurnool, Telangana, India

A Shankar

Scientist, Krishi Vigyan Kendra

Palem, Nagarkurnool,

Telangana, India

\section{B Rajshekar}

Scientist, Krishi Vigyan Kendra

Palem, Nagarkurnool,

Telangana, India

\section{K Ramakrishna}

Scientist, Krishi Vigyan Kendra Palem, Nagarkurnool,

Telangana, India

\section{Assessment of effectivness of protective clothing while spraying pesticides}

\author{
Dr. Afifa Jahan, Mandla Rajashekhar, Dr. T Prabhakar Reddy, A \\ Shankar, B Rajshekar and K Ramakrishna
}

DOI: https://doi.org/10.22271/chemi.2020.v8.i3w.9433

\begin{abstract}
Farming without spraying pesticides is unheard of, unless it is organic farming. Pesticide residues are reported to cause health hazards to many farmers globally. Hence the present study aims at studying the effectiveness of protective clothes while spraying pesticides. The protective clothing ensemble includes scarf/cap (head cover), glasses (eye cover), mask (mouth cover), gloves (hands cover), shirt (body cover), pant (legs cover) and boots (feet cover). The results of three year data shows that $80 \%$ of the people have encountered health problems caused due to spraying when protective aids but the same was reduced after usage of protective clothing. All the subjects were of the opinion that the protective clothing was comfortable to use, suitable to the farming operations and was durable as well.
\end{abstract}

Keywords: Assessment of effectiveness protective clothing while spraying pesticides

\section{Introduction}

Personal protective equipment (PPE) will minimize the harmful effects of pesticide residues on human body. Protective clothing is easy to wear and comfortable and mitigates the adverse effects of spraying. Due to its material and color of the fabric, it does not absorb heat. It is provided with mouth/ nose cap, which do not allow the inhalation of sprays and other dust particles in the air. Occupational exposure to pesticides often occurs in the case of agricultural workers in open fields and greenhouses, workers in the pesticide industry, and exterminators of house pests ${ }^{[1]}$. In open field environment several factors can affect exposure during pesticide handling ${ }^{[2]}$. Almost 1.3 billion workers worldwide suffer from occupational injuries from the use of pesticides and are occupied in agriculture ${ }^{[3]}$. Every year, almost 17,000 workers in agriculture are under lethal effects of pesticides such as carcinogenic, mutagenic and teratogenic according to the records of ILO (International Labor Organization) ${ }^{[4]}$. In India $50 \%$ of the population depend on agriculture for their livelihood. In agriculture usage of pesticides for the management of pests is most common but indiscriminate usage of pesticides leads to a wide range of problems ${ }^{[5]}$. The nutritional value of the most of the crops is enhanced due to the application of pesticides ${ }^{[6,7]}$. There are also many other kinds of benefits that may be attributed to pesticides, but these benefits often go unnoticed by the general public ${ }^{[8,9]}$. Among all the residues, pesticide residues are the most harmful because of the possibility of the deposition on body when farmers fail to wear the protective clothing while spraying of harmful pesticides. Personal protective equipment (PPE) is central in discussions of chemical risk prevention in agriculture. PPE includes skin and eye protective equipment (gloves, coveralls, safety shoes, helmets, and goggles) and respiratory protective equipment (respirators). Especially, in these situations, operators' health can be seriously affected, since pesticides can cause chronic and acute effects on human health ${ }^{[10]}$. Most of the pesticides enter into the human body through the oral route, dermal exposure, and exposure via inhalation. Yarpuz- Bozdogan and Bozdogan ${ }^{[11]}$ indicated that PPE decreased the maximum risk for workers by $32 \%$, the intermediate risk by $44 \%$, and increased the chances of no risk by $24 \%$. The present on farm testing was conducted to assess the effectiveness of personal protective clothing while spraying of harmful pesticides in farmers field of Nagarkurnool district, Telangana.
Corresponding Author: Dr. Afifa Jahan

Scientist, Krishi Vigyan Kendra

Palem, Nagarkurnool,

Telangana, India 


\section{Methodology}

The present study was conducted at Nagarkurnool district of Telangana state from 2017 to 2019 . Ten subjects $(n=10)$ were chosen for the study which continued for a span of three years. The selected subjects were first tested for their knowledge levels on protective clothing through questionnaires. Later the problems encountered while spraying before usage of protective clothing was collected through questionnaire. Method demonstration and awareness camps were conducted to the selected subjects and each of the subjects were provided with the protective clothing kit. The cost of the protective clothing kit was Rs 1500/- which includes a head cap, mask, glasses, white starched kurta, starched white pants and boots. The usage of protective clothing while spraying pesticides, do's and don'ts were explained along with precautions to be taken. Initially they were given demostrations and later monitored while sparaying chemicals. The subjects were sensitized through multiple dramas and skits regarding the importance of PPE, technology

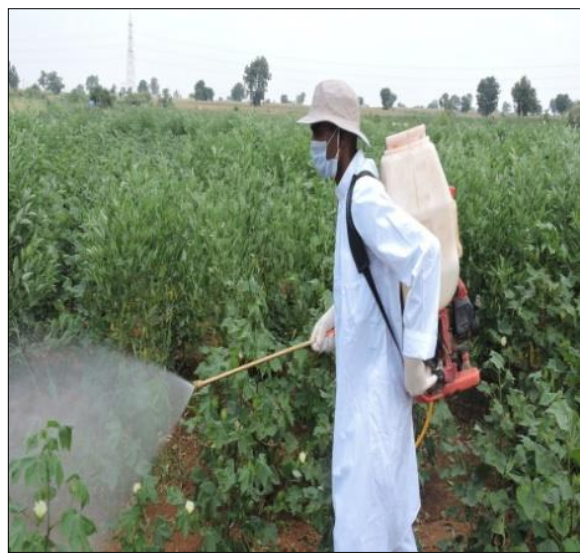

Precautions to be taken by farmers while spraying

1. Wear protective clothing.

2. Do not eat, drink or smoke while using pesticides/ insecticides.

3. Keep them dry but away from fires and out of direct sunlight.

4. Store pesticides in a place that can be locked and is not accessible to unauthorized people or children.

5. Left-over insecticide suspension can be disposed off safely by pouring it into a specially dug hole in the ground. (Dig a hole at least 100 metres away from streams, wells and houses.)

6. Use suitable equipment for measuring out, mixing and transferring pesticides

7. Do not stir liquids or scoop pesticide with bare hands.

8. Use the pressure-release valve of the pump or a soft probe to clear blockages in the nozzle.

9. Wash the hands and face with soap and water each time the pump has been refilled.

10. Take a shower or bath at the end of the day.

11. Spray workers should wear overalls or shirts with long sleeves and trousers, a broad-brimmed hat, a turban or other headgear and sturdy shoes or boots.

12. The mouth and nose should be covered with a simple device such as a disposable paper mask, a surgical-type disposable or washable mask, or any clean piece of cotton.

13. In hot and humid climate wearing of additional protective clothing may be uncomfortable, and pesticides should therefore be applied during the cooler hours of the day. acceptance and attitude change towards the usage of protective clothing. The assessment of protective clothing and acceptability was conducted through the questionnaire provided by AICRP Home Science, Rajendranagar, Hyderabad. The data on adoption feasibility of the respondents regarding usage of protective clothing was also collected.

Results and discussion: The present study was carried for three years from 2017-2019. A protective clothing kit consisting of white kurta or long shirt and pant, starched cap, mask, glasses, hand gloves and boots were given to 10 subjects. The data before wearing protective clothes were recorded (image 1.) and after using protective clothing was collected (image 2.) A method demonstration was given on appropriate use of protective clothing (as in image 3.) Precautions to be taken while spraying pesticides were explained as mentioned below.

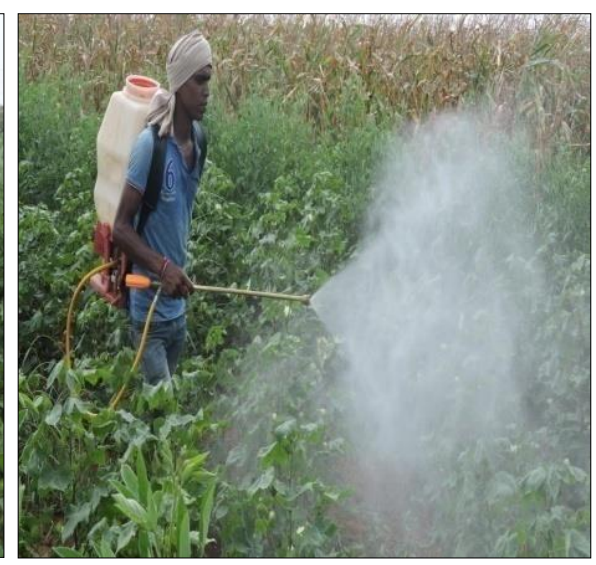

14. After use, the clothes should be rinsed with warm water before they are taken off. At the end of each working day they should be washed inside and outside and starch should be applied.

15. Clothing should be kept in a good state and should be inspected regularly for tears or worn areas through which skin contamination might occur.

The health issues were recorded before and after usage of protective clothing which is explained in table I and Table II.

Table I: Problems encountered while spraying before usage of protective clothing.

\begin{tabular}{|c|c|c|c|}
\hline & $\begin{array}{c}\text { Problems encountered while spraying after before } \\
\text { of protective clothing }(\mathbf{n}=\mathbf{1 0})\end{array}$ & Yes & $\mathbf{N o}$ \\
\hline 1. & Eye irritation/burning sensation/blurred vision & 10 & -- \\
\hline 2. & Watering of eyes & 10 & -- \\
\hline 3. & Skin allergy & 10 & -- \\
\hline 4. & Nausea & 10 & -- \\
\hline 5. & Vomiting & 4 & 6 \\
\hline 6. & Giddiness & 6 & 4 \\
\hline 7. & Headache & 8 & 2 \\
\hline 8. & Sweating & 10 & \\
\hline 9. & Breathlessness & 10 & -- \\
\hline 10. & -- & 10 \\
\hline 11. & Allergic bronchitis & 10 & -- \\
\hline 12. & 8 & 2 \\
\hline 13. & Dust accumulation on body & 6 & 4 \\
\hline 14. & Foot / Hand irritation & 5 & 5 \\
\hline 15 & Excessive salivation & 10 & -- \\
\hline 16. & Running nose & 10 & -- \\
\hline
\end{tabular}




\begin{tabular}{|l|c|c|c|}
\hline 17. & Wheezing & 7 & 3 \\
\hline 18. & 5 & 5 \\
\hline 19. & 10 & \\
\hline 20. & Chest pain and tightness & 5 & 5 \\
\hline 21. & Abdominal pain & 10 & \\
\hline 22. & 2 & 8 \\
\hline 23 & Murning sensation in mouth and throat & - & 10 \\
\hline
\end{tabular}

The response of 10 subjects before use of protective clothing as in table I is for Eye irritation/ burning sensation/blurred vision, watering, Skin allergy, Nausea, Sweating, Breathlessness, Dust accumulation on body, Fatigue / extreme weakness, Sneezing, Cough and Burning sensation in mouth and throat was reported by 10 out of 10 subjects,

Whereas 4 out of 10 subjects reported vomiting, 6 out of 10 reported giddiness, 8 out of 10 reported headache as a serious problem, 8 out of 10 reported foot / hand irritation, 6 out of 10 reported excessive salivation, running nose was reported by 5 out of 10,7 out of 10 reported wheezing, chest pain and tightness was reported by 5 out of 10,5 out of 10 reported abdominal pain and 2 out of 10 reported muscle twitching. Allergic bronchitis and unconsciousness were not reported by any of the subjects.

Table II: Problems encountered while spraying after usage of protective clothing.

\begin{tabular}{|c|c|c|c|}
\hline & $\begin{array}{c}\text { Problems encountered while spraying after usage } \\
\text { of protective clothing }(\mathbf{n}=\mathbf{1 0})\end{array}$ & Yes & No \\
\hline 1. & Eye irritation/burning sensation/blurred vision & - & 10 \\
\hline 2. & Watering of eyes & - & 10 \\
\hline 3. & Skin allergy & - & 10 \\
\hline 4. & Nausea & - & 10 \\
\hline 5. & Vomiting & - & 10 \\
\hline 6. & Giddiness & - & 10 \\
\hline 7. & Headache & - & 10 \\
\hline 8. & Sweating & 3 & 7 \\
\hline 9. & Breathlessness & - & 10 \\
\hline 10. & Allergic bronchitis & -- & 10 \\
\hline 11. & Dust accumulation on body & - & 10 \\
\hline 12. & Foot / Hand irritation & - & 10 \\
\hline 13. & Excessive salivation & 2 & 8 \\
\hline 14. & Running nose & - & 10 \\
\hline 15 & Fatigue / extreme weakness & 2 & 8 \\
\hline 16. & Sneezing & - & 10 \\
\hline 17. & Wheezing & - & 10 \\
\hline 18. & Chest pain and tightness & 1 & 9 \\
\hline 19. & Cough & - & 10 \\
\hline 20. & Abdominal pain & 2 & 8 \\
\hline 21. & Burning sensation in mouth and throat & - & 10 \\
\hline 22. & Muscle twitching & - & 10 \\
\hline 23 & Unconsciousness & - & 10 \\
\hline
\end{tabular}

The response of 10 subjected after using protective clothing as in table II indicates that 10 out of 10 do not have the problem of eye irritation/ watering of eye, skin allergies, nausea, vomiting, giddiness, headache, breathlessness, allergic bronchitis, dust accumulation, foot / hand irritation, running nose, sneezing, cough, burning sensation in mouth and throat, muscle twitching and Unconsciousness.

Whereas 3 out of 10 reported sweating, 2 out of 10 reported excessive salivation, 1 out of 10 reported chest pain and tightness and 2 out of 10 reported abdominal pain.

Table III: Assessment of protective clothing.

\begin{tabular}{|c|c|c|c|c|c|c|}
\hline & $\begin{array}{c}\text { Functional features of the } \\
\text { garment }(n=10)\end{array}$ & Excellent & Good & Fair & poor & $\begin{array}{c}\text { v. } \\
\text { poor }\end{array}$ \\
\hline 1. & \multicolumn{6}{|c|}{ Suitability assessment } \\
\hline $\mathrm{a}$ & Appearance & 2 & 8 & - & - & - \\
\hline $\mathrm{b}$ & Size assortment (length, width) & 3 & 7 & - & - & - \\
\hline c & Coverage of whole body & 10 & - & - & - & - \\
\hline $\mathrm{d}$ & Fit/ grip (wrist/ fingers) & 10 & - & - & - & - \\
\hline \multicolumn{7}{|c|}{ Comfortability } \\
\hline $\mathrm{a}$ & Easy to wear & 1 & 9 & - & - & - \\
\hline $\mathrm{b}$ & Easy to remove & 1 & 9 & - & - & - \\
\hline c & Grip while working & 7 & 3 & - & - & - \\
\hline d & $\begin{array}{c}\text { Can wear the garment for } 2-3 \\
\text { hours }\end{array}$ & - & 3 & 7 & - & - \\
\hline \multicolumn{7}{|c|}{ Durability/Serviceability } \\
\hline a & $\begin{array}{l}\text { Fabric used protects from } \\
\text { external factors }\end{array}$ & - & 8 & 2 & - & - \\
\hline $\mathrm{b}$ & Absorbency of perspiration & 2 & 8 & - & - & - \\
\hline \multicolumn{7}{|c|}{ Adoption Feasibility } \\
\hline $\mathrm{a}$ & Reasonable (INR 1500/-) & - & - & 10 & - & - \\
\hline
\end{tabular}

The protective clothing given for the subjects was assessed based on suitability, comfort, and durability and adoption feasibility.

Under suitability assessment $20 \%$ of the subjects reported the appearance was excellent and $80 \%$ reported it to be good in the appearance whereas for size assortment (length, width) $30 \%$ reported excellent and $80 \%$ reported to be good. All the respondents reported excellent for coverage of whole body and fit/ grip (wrist/ fingers)

Under comfortability $10 \%$ reported excellent and $90 \%$ reported to be good in easy to wear and easy to remove. For grip while working category $70 \%$ reported excellent and $30 \%$ reported to be good. When asked whether they can wear the garment for 2-3 hours $70 \%$ were affirmative satisfied and $30 \%$ veoted the idea.

Under durability/serviceability component, fabric used for study protects from external factors $20 \%$ reported fair and $80 \%$ reported to be good; for absorbency of perspiration $20 \%$ reported excellent and $80 \%$ reported to be good.

The response of the subject under Adoption Feasibility reasonable was reported to be fair as the whole set including cap mask shirt pant glasses gloves and boots include Rs 1500/. All the subjects indicated 'fair' for the cost of PPE kit (₹.1500) which includes cap, mask, shirt, pant, glasses, gloves and boots, meaning that the cost was fairly reasonable for the number of items in the kit.

Table IV: Adoption feasibility of the respondents regarding before and after usage of protective clothing

\begin{tabular}{|c|c|c|c|c|c|c|c|}
\hline \multirow{2}{*}{$\begin{array}{l}\text { S. } \\
\text { No }\end{array}$} & \multirow{2}{*}{ Statements } & \multicolumn{3}{|c|}{$\begin{array}{c}\text { Before usage of protective } \\
\text { clothing }\end{array}$} & \multicolumn{3}{|c|}{$\begin{array}{l}\text { After usage of protective } \\
\text { clothing }\end{array}$} \\
\hline & & $\begin{array}{l}\text { Strongly } \\
\text { Agree }\end{array}$ & Agree & \begin{tabular}{c|c} 
Dis \\
agree
\end{tabular} & $\begin{array}{l}\text { Strongly } \\
\text { Agree }\end{array}$ & Agree & $\begin{array}{l}\text { Dis } \\
\text { agree }\end{array}$ \\
\hline 1. & $\begin{array}{l}\text { Old shirt protect neck from dust and other organic matter, so there is no need of } \\
\text { specially designed protective clothing. }\end{array}$ & 9 & 1 & - & - & - & 10 \\
\hline 2. & I feel good with old shirt as I am habitual to wearing it. & 10 & - & - & - & - & 10 \\
\hline 3. & Functional features/fasteners used in protective clothing do not cause pinching. & 10 & - & - & 5 & 5 & - \\
\hline 4. & Protective clothing though looks different still one should wear these as health & - & 2 & 8 & 10 & - & - \\
\hline
\end{tabular}




\begin{tabular}{|c|c|c|c|c|c|c|c|}
\hline & protection is important than looks. & & & & & & \\
\hline 5. & $\begin{array}{c}\text { One must wear protective clothing to avoid health problems during agricultural } \\
\text { activities. }\end{array}$ & - & 5 & 5 & 8 & 2 & - \\
\hline 6. & $\begin{array}{l}\text { It is better to spend money on protective clothing rather than to spend money on } \\
\text { health diseases/problems. }\end{array}$ & - & 3 & 7 & 10 & - & - \\
\hline 7. & Protective clothing are the needs of every farm workers. & - & 3 & 7 & 10 & - & - \\
\hline 8. & $\begin{array}{l}\text { To avoid health problems faced by farm workers with the use of normal } \\
\text { clothing, everyone will use protective clothing during working hours }\end{array}$ & - & 2 & 8 & 8 & 2 & - \\
\hline
\end{tabular}

\section{Conclusion}

Protective clothing is easy to wear and comfortable and mitigates the adverse effects of spraying. Due to its material and color of the fabric, it does not absorb heat. It is provided with mouth/ nose cap, which do not allow the inhalation of sprays and other dust particles in the air. The results of three year data shown that $80 \%$ of the people studied are found to be encountered with health problems caused due to spraying without wearing protective aids but the same was reduced after usage of protective clothing. $100 \%$ of the studied sample accepted the suitability and durability of the protective clothing while spraying pesticides as well as comfortable to use.

Acknowledgement: The authors acknowledge AICRP Home Science Textiles department for providing the protective clothing for the study and ICAR for proving grants for this "on farm testing".

\section{References}

1. Christos A. Damalas, Ilias G. Eleftherohorinos. Pesticide Exposure, Safety Issues, and Risk Assessment Indicators. Int. J. Environ. Res. Public Health. 2011; 8:1402-1419.

2. Fenske RA, Day EW. Jr. Assessment of exposure for pesticide handlers in agricultural, residential and institutional environments. In Occupational and Residential Exposure Assessment for Pesticides; Franklin, C.A., Worgan, J.P., Eds.; John Wiley \& Sons: Chichester, UK, 2005, 13-43.

3. International Labour Office (ILO): Safety and health in agriculture. SafeWork, programme on safety, health and the environment. Switzerland: Labour Department International Labour Office; 2000, 24.

4. Palis FG, Flor RJ, Warburton H, Hossain M. Our farmers at risk: behavior and belief system in pesticide safety. $\mathrm{J}$ Public Health. 2006; 28:43-48.

5. Rajashekhar M, Rajashekar B, Reddy TP, Ramakrishna K, Shankar A, Jahan A et al. J.M. IPM: An ecofriendly and low cost technology in arresting pest complex for higher net returns in cotton. Journal of Entomology and Zoology Studies. 2020; 8(2):1726-1728.

6. Boxall RA. Post-harvest losses to insects-a world overview. Int. Biodeter. Biodegr. 2001; 48:137-152.

7. Narayanasamy P. Postharvest Pathogens and Disease Management; John Wiley \& Sons: New York, NY, USA, 2006.

8. Cooper J, Dobson H. The benefits of pesticides to mankind and the environment. Crop Prot. 2007; 26:13371348.

9. Damalas CA. Understanding benefits and risks of pesticide use. Sci. Res. Essays. 2009; 4:945-949.

10. Recena MCP, Pires DX, Caldas ED. Acute poisoning with pesticides in the state of Mato Grosso do Sul, Brazil. Sci Total Environ. 2006; 357:88-95.

11. Yarpuz-Bozdogan N, Bozdogan AM. Pesticide exposure risk on occupational health in herbicide application. Fresenius Environ Bull. 2016; 25:3720-3727. 